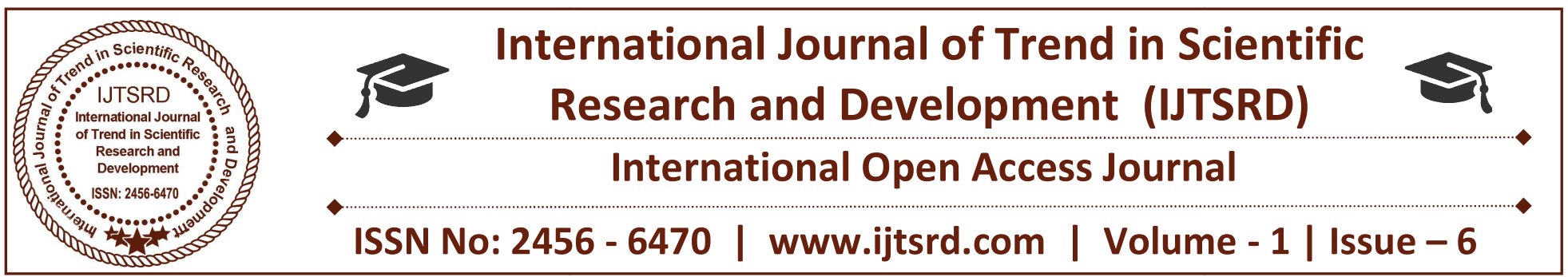

\title{
Literature Review on Stay off Stealers (SOS) Home Security System
}

\author{
Harshal Bhagwat \\ Dept. of EXTC, Finolex academy of Management \& \\ Technology, Ratnagiri
}

\section{ABSTRACT}

Now a day's people are going through many problems related to security of systems, so security is the most important thing nowadays. In this paper, we try to mention all study related to the security system, basically the system which related to the door lock and main entrance of buildings, which is helpful to prevent an issue like robbery. In past years, the research is gone on different door lock security systems like systems which provide indications of the buzzer. Due to the modern technology, some door lock security systems are based on Arduino, raspberry, the microcontroller also with subcomponent like GPS, GSM, RFID, face scanning, biometric scanning etc. each component is defined with their positive and negative points. In most of systems, SMS technique is used for communication to the system will become cost-effective, more reliable and it will take less time to deliver the message. As security having a big issue nowadays, the security monitoring systems today need to make use of the latest technology. In some papers, the authors have presented door lock security monitoring system based on embedded and Zigbee and sometimes the lock is protected by automatic password hence it could not easily hack by hackers. Also, the raised security systems are available based on Android platform, wireless techniques, and embedded systems. A lot of modification takes places in various Door lock security from the last few years, in next coming years, many changes will take place.

Keywords: Door Lock Security, GSM, RFID, SMS, buzzer, Biometrics, Password

\author{
Kaustubh Akhade \\ Dept. of EXTC, Finolex academy of Management \& \\ Technology, Ratnagiri
}

\section{INTRODUCTION}

Security is most important factor in daily life so providing protection to it is necessary. Ensuring safety of peoples and their valuable things is very important for the prevention of illegal handling. Hence, need to focus on parameters like door lock system and main gate entrance. Even with the use of hard metal locks, the crime, robberies get happened because of modern mechanical equipment's it gets break easily. So, there is need to invent another kind of locks which cannot be easily broken. So, many researchers design different kinds of door lock digitally and on software basis also with automatic password based door locks etc. which are mostly used for home and offices.

To stop unauthorized entry we use different techniques like by using RFID tag, face recognition, iris scanning, fingerprint scanning and other biometric techniques. Nowadays, advanced automatic door security systems are available with this kind of advanced techniques which is secure organization intelligently. Hence, people need not worry about the home security though they are away from home. But as per technology rise, the mind of thief also gets intelligent so we have to design a circuitry which will also be intelligent and useful to provide the best protection to our home and offices

\section{LITERATURE SURVEY}

1) Design and Implementation of Security Systems for Smart Home based on GSM technology

This paper suggests us about home security by using two methods. First by using web camera and second 
by using GSM technique in the first method whenever there is any motion or movement take place in front of web camera then it provides output to controller and alarm gets on. In second method GSM techniques use basically GSM is technology which sends the message as per signal provided to it and those numbers which are save in SIM card those all numbers gets a message of alert. We use GSM GPS Module (sim548c) and Atmega644p microcontroller, sensors, and buzzers [1].

\section{2) A Survey on Internet of Things Based Home Automation System}

A low-cost smart home system, which uses an Android application to communicate with the cloud and provides switching functionalities, is presented. The System eliminates the use of Personal Computer (PC) and other Computer Peripherals which leads to the overall reduction in the cost of the system. Unlike the similar system which uses either of the Bluetooth module networks, the proposed system uses the Internet of Things (IoT) for controlling the Electrical/Electronic Appliances, remotely. Switches of Electrical/Electronic appliances are integrated into the system in order to demonstrate the effectiveness and feasibility of the system [2].

\section{3) A Digital Security System with Door Lock System Using RFID Technology}

In this paper, we studied RFID component how to use, How to interface and its various applications. In the projects of door lock system mostly passive RFID is used as compared to active. This is implemented is three spaces using central database system. The secure space located on same or different part of buildings. The system used hardware as well as software. The hardware components are RFID reader, tags, USB connections and connecting cables etc. In this paper if person has a tag that tags place near to RFID device if tag match with RFID device than person signifies as authorizes and door gets open vice versa if tag does not match the person is unauthorized and door will not get open in this way we can restrict intruder entry and security of home get raise [3].

\section{4) Arduino based smart RFID security and} attendance system with audio acknowledgement

In this paper, we studied a secure system that provides information about authorized and unauthorized persons. In this system when card brought near to the RFID module it reads the card information and it compares with the data in the program memory and displays authorized or unauthorized entry. The door opens for authorized entry and marked the attendance corresponding to that code id and save in excel sheet format in SD card and after that display, it's all information on the LCD [4].

\section{5) Bluetooth Based Systems}

Bluetooth used system is a bit like savvy house innovations that utilize Bluetooth function available in smart devices. The framework using Bluetooth turns out to be more simple and productive for proper utilization. Such systems are generally based on Arduino platform. The hardware of such framework is the combo of android smartphones and Bluetooth module. Arduino microcontroller here is acting as a controller and solenoid can be acting as an output of locking system.

\section{6) Access control of door and home security by raspberry pi through internet}

In this modern world, robbers are also becoming intelligent. In order to protect our home from the unwanted person, the main door of the home should have a good security level. In this paper, writers have designed a system which will allow only authorized entry of persons in noise. They tried to connect the door to the internet with the help of IoT. In this system, the owner will get one notification when any person comes to the doorstep. The owner can see the live streaming of video and he can keep which on that person. If the owner has to give some message to that person then the text entered by owner will display on a screen placed on the door. According to that message, the person can do the task. In this way, the owner can monitor his house from anywhere with help of internet [5].

\section{7) Smart surveillance monitoring system using raspberry pi and PIR sensor}

In this paper, a writer has developed a monitoring system for house using the raspberry pi and PIR sensor. Here they have used $3 \mathrm{G}$ dongle to connect to the internet. In this raspberry pi, pocket-sized computer records and live stream the video footage on pi camera over the internet. They have used PIR sensor for detection of the human being. As soon as 
human presence is been detected by PIR, an owner gets the live streamed camera output along with notification with the help of internet. In this way, the system works as the monitoring system for a home [6].

\section{8) Home Automation and Security System Using Android ADK}

This paper gives us information about how we successfully secure our home and how we automate home by using android ADK. The design is based on a standalone embedded system board Android ADK (Accessory Development Kit) at home. In this project, home appliance gets firstly connected to ADK device and then it developed communication between ADK device and android mobile. Home equipment is connected to the embedded system board and a signal is passed to the ADK.in this system authentication provided to the owner of the house. The device with low cost and scalable to less modification to the core is much important. Basically, the main aim of the project is to monitor home appliances using mobile, tablets [7].

\section{SUMMARY}

Nowadays widely used door lock system based on intelligent digitized technique is studied and their problems are shown in table 1. As per the requirements, authors developed the systems. And as per our knowledge, not a single system is suitable for all types of applications, day by day technologies are developing and techniques of robbery are also developing. So, need is to develop a new smart and unbreakable technique in further studies.
Table 1: Recently Proposed Different Door Lock Security Systems using Various Techniques with their Problems

\begin{tabular}{|c|c|c|}
\hline $\begin{array}{l}\text { SR } \\
\text { No. }\end{array}$ & $\begin{array}{l}\text { Specific } \\
\text { Techniques }\end{array}$ & Problems \\
\hline 1 & $\begin{array}{l}\text { Face } \\
\text { Recognition }\end{array}$ & $\begin{array}{l}\text { 1) Image quality } \\
\text { 2) Face angle } \\
\text { 3) Processing and } \\
\text { storage }\end{array}$ \\
\hline 2 & $\begin{array}{l}\text { Palmtop } \\
\text { Recognition }\end{array}$ & Less resolution. \\
\hline 3 & $\begin{array}{l}\text { Face Recognition } \\
\text { with GSM } \\
\text { Technology and E- } \\
\text { Mail } \\
\text { Facility }\end{array}$ & $\begin{array}{l}\text { Affect when person } \\
\text { with glasses or change } \\
\text { in light focus. }\end{array}$ \\
\hline 4 & $\begin{array}{l}\text { Iris scanner, } \\
\text { Vein } \\
\text { Detection, } \\
\text { Unique Code }\end{array}$ & Having less memory \\
\hline 5 & Digital Code Lock & $\begin{array}{l}\text { Can't change the } \\
\text { password, during power } \\
\text { failure system will gets } \\
\text { off. }\end{array}$ \\
\hline
\end{tabular}

\section{CONCLUSION}

Today's world security system needs to be intelligent. The need for an advanced door lock security systems using new technologies is increasing day by day as security becomes a very important or serious issue for everybody. Due to the recent trends in various methods of security for home, buildings, companies ${ }^{\text {ee }}$ vehicles etc., there is no need to worry about this security any longer, as automatic security systems are here to deal with it. This paper tries to show all recent security protection system including all door locking system. 


\section{REFERENCES}

1) Jayashri Bangali and Arvind Shaligram, "DESIGN AND IMPLEMENTATION OF SECURITY SYSTEMS FOR SMART HOME BASED ON GSM TECHNOLOGY', International Journal of Smart Home, Vol.7, No.6 (2013).

2) S Somaya, Malini Chavali, Suchi Gupta, Niharika rao, "INTERNET OF THINGS BASED HOME AUTOMATION SYSTEM” ,2016 IEEE International Conference on Recent Trends in Electronics, Information \& Communication Technology (RTEICT), 09 January 2017

3) Gyanendra K Verma, Pawan Tripathi " $A$ DIGITAL SECURITY SYSTEM WITH DOOR LOCK SYSTEM USING RFID TECHNOLOGY" International Journal of Computer Applications (0975 - 8887), Volume 5- No.11, August 2010.

4) Y Mishra, GK Marwah, S Verma, "ARDUINO BASED SMART RFID SECURITY AND ATTENDANCE SYSTEM WITH AUDIO ACKNOWLEDGEMENT" International Journal of Engineering Research \& Technology (IJERT) IJERT ISSN: 2278-0181 IJERTV4IS010401 www.ijert.org (This work is licensed under a Creative Commons Attribution 4.0 International License.) Vol. 4 Issue 01,January-2015
5) Md. Nasimuzzaman Chowdhury, Md. Shiblee Nooman , Srijon Sarker, "HOME SECURITY USING RASPBERRY PI",International Journal of Scientific \& Engineering Research, Volume 4, Issue , 11 NOV-2013.

6) Sanjana Prasad, P.Mahalakshmi, A.John Clement Sunder, R.Swathi," SMART SURVEILLANCE MONITORING SYSTEM USING RASPBERRY PI AND PIR SENSOR", Sanjana Prasad et al, / (IJCSIT) International Journal of Computer Science and Information Technologies, Vol. 5 (6)

, 2014, 7107-7109

7) Deepali Javale , Mohd. Mohsin , Shreerang Nandanwar, Mayur Shingate , "HOME AUTOMATION AND SECURITY SYSTEM USING ANDROID ADK",International Journal of Electronics Communication and Computer Technology (IJECCT) Volume 3 Issue 2 (March 2013). 